Jurnal Keperawatan Silampari

Volume 3, Nomor 2, Juni 2020

e-ISSN: 2581-1975

p-ISSN: 2597-7482

DOI: https://doi.org/10.31539/jks.v3i2.1076

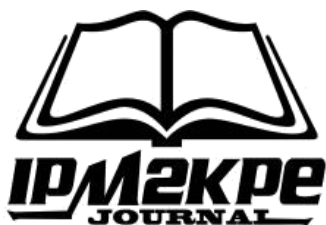

\title{
PEMBERIAN LARUTAN GARAM TERHADAP PENURUNAN KADAR FORMALIN PADA TAHU
}

\author{
Rosnita Sebayang ${ }^{1}$, Kesatria Bayu Kencana ${ }^{2,}$ Ines Samosir ${ }^{3}$ \\ Universitas Katolik Musi Charitas Palembang ${ }^{1,2,3}$ \\ ros.sebayang@gmail.com ${ }^{1}$
}

\begin{abstract}
ABSTRAK
Tujuan penelitian mengidentifikasi pengaruh kadar formalin dalam tahu, terhadap perebusan pada larutan garam dapur dengan cara perebusan dengan beberapa suhu. Metode penelitian ini adalah eksperimen laboratorium, untuk mengidentifikasi penurunan kadar formalin dalam tahu putih yang ditambahkan larutan garam konsentrasi 1\%, 2\%, 3\% dengan cara perebusan selama 10, 15, 20 menit. Hasil Penelitian berdasarkan analisis uji anova, ada pengaruh pemanasan sampai mendidih $\left(100^{\circ} \mathrm{C}\right)$, dalam larutan garam $1 \% p$ value $=0,000$. Simpulan, terdapat pengaruh pemberian larutan garam terhadap penurunan kadar formalin pada tahu.
\end{abstract}

Kata Kunci: Formalin, Garam, Tahu

ABSTRACT

The study aimed to identify the effect of formalin in tofu on boiling in a solution of kitchen salt by cooking with several temperatures. This research method is a laboratory experiment to determine a decrease in formalin in white tofu added with a salt solution concentration of 1\%, 2\%, 3\% by boiling for 10, 15, 20 minutes. Research results based on ANOVA test analysis, there is the effect of heating to boiling $(1000 \mathrm{C})$, in a $1 \%$ salt solution $p$-value $=0,000$. In conclusion, there is an effect of giving a salt solution to decrease formalin levels in tofu.

Keywords: Formalin, Salt, Tofu

\section{PENDAHULUAN}

Akhir-akhir ini di Indonesia banyak terjadi permasalahan konsumen khususnya pada bidang pangan. Diantaranya adalah kasus-kasus tentang masalah penyalahgunaan bahan berbahaya pada produk pangan ataupun bahan yang diperbolehkan tetapi melebihi batas yang ditentukan. Produk pangan yang sering dikonsumsi oleh masyarakat yang merupakan sumber protein nabati, tidak disadari telah terkontaminasi oleh bahan berbahaya. Produk pangan yang dimaksud salah satunya adalah tahu (Manalu, Musthari, 2019).

Formalin merupakan bahan tambahan pangan kimia yang penggunaannya dilarang karena berbahaya bagi kesehatan manusia. Hal tersebut karena Formalin dapat menyebabkan efek langsung pada kesehatan manusia seperti iritasi, alergi, kemerahan, sakit dada, jantung berdebar, mata berair, pusing, mual, muntah, sakit perut, dan diare. Jika dikonsumsi secara terus menerus dalam jangka waktu lama, dapat menyebabkan gangguan pencernaan, gangguan hati, gangguan ginjal, gangguan pancreas, gangguan 
sistem saraf pusat, gangguan menstruasi, dan dapat menyebabkan kanker (Pusparini, Triyantoro, 2018).

Efek toksik formalin yang tinggi dan bersifat karsinogenik maka Badan Pengawasan Obat Dan Makanan (BPOM) melarang penambahan formalin dalam makanan. Pengawet alami banyak digunakan sebagai alternative pengganti pengawet berbahaya, selain mudah didapat, pengawet alami jauh lebih aman dan sehat untuk dikonsumsi (Burhan, 2018).

Masalah utama pada produksi tahu adalah masa simpan tahu yang sangat singkat. Pada umumnya tahu segar hanya dapat disimpan lebih satu hari pada suhu kamar. Apabila penyimpanan tahu dilakukan lebih dari dua hari pada suhu kamar, maka dapat mengakibatkan tahu berasa asam dan semakin lama semakin membusuk sehingga tidak layak dikonsumsi. Singkatnya masa simpan tahu ini mengakibatkan produksi tahu yang harus dilakukan setiap hari dengan jumlah produksi terbatas untuk menghindari kerusakan tahu (Nuranisa et al., 2018).

Pengawet alami banyak digunakan sebagai alternatif pengganti pengawet berbahaya, selain mudah didapat, pengawet alami jauh lebih aman dan sehat untuk di konsumsi. Pengawet alami seperti jahe, kunyit, garam, gula, jeruk nipis dan bawang putih. Garam juga digunakan untuk menurunkan kadar formalin dimulai dari kelarutan garam dapur dalam air yang menyebabkan kelarutan oksigen dalam air menurun, dan denaturasi protein, sehingga aktifitas enzyme berkurang. Garam dapat menurunkan kadar formalin pada tahu karena perbedaan tekanan osmosis antara sel padatan dengan larutan garam (Ernawati et al., 2017).

Maka dari itu perlu dilakukan upaya-upaya untuk mengawetkan tahu agar dapat disimpan lebih lama dalam suhu kamar. Oleh karena itu, perlu dilakukan pencarian bahan pengawet tahu yang aman, namun tetap murah dan terjangkau oleh masyarakat (Iftriani et al., 2016). Penelitian Amilustavilova et al., (2017) didapatkan hasil uji statistik paired sample t-test didapatkan nilai p 0,01 sehinggan dapat disimpulkan ada pengaruh perebusan dengan air mendidih terhadap kadar formalin pada tahu.

Penurunan kadar formalin pada tahu berformalin setelah direbus selama 10 menit adalah 91,1\%. Penurunan kadar formalin pada tahu berformalin dengan perlakuan perendaman dalam air panas selama 10 menit adalah 69,5\%. Perebusan tahu berformalin menurunkan kadar formalin lebih besar dibandingkan perendaman tahu dalam air panas (Widayona, Nasution, 2018).

Penelitian yang dilakukan (Indri et al., 2018) Hasil penelitian didapatkan panjang gelombang optimum $570 \mathrm{~nm}$ dan waktu kestabilan optimum selama 15 menit. Kadar formalin awal pada tahu yang telah direndam formalin $1 \%$ adalah $338,09 \mathrm{mg} / \mathrm{kg}$, Konsentrasi larutan jeruk nipis tertinggi adalah 6\% dan waktu perendaman 90 menit dapat menurunkan kadar formalin sebanyak 73,07\%.

Penelitian Cahyadi et al., (2020) hasil uji kuantitatif perendaman air kunyit, air cuka dan air garam selama 60 menit menunjukkan penurunan konsentrasi formalin berturut-turut sebesar 22,56\%, 25,54\% dan 55,33\%. Larutnya formalin pada air garam menyebabkan kadar formalin dalam tahu berkurang. Kemampuan melarutkan yang tinggi yang dimiliki air garam inilah yang menyebabkan efektivitas perendaman dengan air garam memiliki angka yang tertinggi dalam mereduksi kadar formalin pada tahu jika dibandingkan dengan perendaman lainnya yaitu air kunyit dan air cuka.

Dari beberapa penelitian yang sudah dilakukan dapat diketahui bahwa keberadaan formalin dalam makanan sudah diteliti dalam beberapa aspek dengan berbagai cara perlakuan untuk mengurangi kadar formalin didalam makanan, namun penelitian ini 
berfokus pada perendaman dengan larutan garam 1, 2, dan 3\%, baru dilakukan pemanasan dengan 2 variasi suhu $50^{\circ} \mathrm{C}$ dan $100^{\circ} \mathrm{C}$ untuk mengurangi kadar formalin pada tahu.

\section{METODE PENELITIAN}

Metode penelitian ini merupakan penelitian eksperimental laboratorium untuk mengidentifikasi penurunan kadar formalin dalam tahu putih yang direndam dengan perebusan dalam larutan garam. Sampel penelitian ini adalah tahu putih yang dijual dipasar tradisional di Kota Palembang dan positif mengandung formalin.Kemudian sampel yang positif ditentukan kadarnya dengan salah satu metode penentuan dengan Asam kromatopat. Tahu yang sudah diketahui kadarnya, dilakukan perendaman dengan larutan garam 1, 2, dan 3\%, baru dilakukan pemanasan dengan 2 variasi suhu $50^{\circ} \mathrm{C}$ dan $100^{\circ} \mathrm{C}$. Setelah perlakuan, baru ditentukan lagi kadar formalin dalam tahu, untuk mengetahui berapa persen penurunan kadar formalin setelah perlakuan.

\section{Prosedur Penelitian}

\section{Pembuatan Larutan Kerja untuk Regresi Linier Metode Asam Kromatopat}

Langkah pertama yang harus dilakukan adalah pembuatan curva kalibrasi yang berfungsi sebagai pembanding dalam menentukan konsentrasi sampel.

Siapkan larutan Induk Formalin dari Merc dengan Konsentrasi 37 \%, kemudian larutan ini diambil dari larutan Formaldehid murni yang konsentrasi $37 \%=370000$ ppm. Selanjutnya pengenceran dilakukan hingga mendapat larutan yang berkonsentrasi 925 ppm, caranya dengan memipet 250 ul larutan induk formalin konsentrasi $37 \%$, kedalam labu ukur $100 \mathrm{ml}$. Dari larutan ini pipet masing-masing 50, 100, 200, 500, dan $1000 \mathrm{ul}$, masukkan dalam labu ukur $100 \mathrm{ml}$, hingga terdapat konsentrasi 0,4625, 0,9250, $1,8500,4,6250$ dan 9,2500 ppm.

Kemudian masing-masing larutan diambil $1 \mathrm{ml}$, masukkan dalam tabung reaksi, tambahkan $5 \mathrm{ml}$ pereaksi asam kromatopat. Setelah selesai dimasukkan dalam penangas air mendidih selama 15 menit kemudian dinginkan, dan baca di Spectrophotometer panjang gelombang $560 \mathrm{~nm}$. Selanjutnya buat kurva kalibrasi untuk menentukan regresi.

\section{Pemeriksaan Kualitatif}

Siapkan larutan asam 0,5 gram asam kromatopat dilarutkan dengan $\mathrm{H}_{2} \mathrm{SO}_{4} 72 \%$. Kemudian timbang tahu yang telah dihomogenkan, gerus dan timbang 10 gram, dan tambahkan aquades $50 \mathrm{ml}$ dalam bekker gelas. Tambahkan $1 \mathrm{ml} \mathrm{H}_{3} \mathrm{PO}_{4}$, centrifus selama 15 menit. Selanjutnya ambil supernatant $1 \mathrm{ml}$, masukkan dalam tabung reaksi, tambahkan $5 \mathrm{ml}$ pereaksi asam kromatopat, panaskan diatas penangans air mendidih, selama 15 menit. Lihat perubahan warna, apabila warna larutan berubah menjadi ungu, berarti positif mengandung formalin. Kemudian dari masing-masing larutan ini di pipetsecara kuantitatif $1 \mathrm{ml}$, masukkan dalam tabung reaksi besar (volume $10 \mathrm{ml}$ ), tambahkan larutan pereaksi asam kromatopat masing-masing $5 \mathrm{ml}$, aduk hingga larutan homogen.

\section{Pemeriksaan secara Kuantitatif}

Timbang sampel $10 \mathrm{gr}$, haluskan, tambah aquades $50 \mathrm{ml}$ aquades dalam bekker gelas.Tambahkan $1 \mathrm{ml} \mathrm{H}_{3} \mathrm{PO}_{4}$, sentrifus dengan kecepatan 3000 ppm selama 15 menit (pakai tabung centrifus setimbang). Pisahkan supernatant sebanyak $1 \mathrm{ml}$, masukkan dalam tabung reaksi, tambahkan pereaksi asam kromatopat $5 \mathrm{ml}$, kemudian tabung 
reaksi masukkan dalam penangas air mendidih selama 15 menit. Dinginkan, dan baca pada Spectrophotometer absorbansi dari warna ungu. Dari pembacaan absorbansi dari sampel dapat dihitung konsentrasi formalin dengan dalam sampel tahu dengan menggunakan rumus regresi linier.

\section{HASIL PENELITIAN}

Uji Kualitatif

Tabel. 1

Hasil Uji Kualitatif

\begin{tabular}{ccc}
\hline No & Kode Sampel & Hasil Uji \\
1 & A & - \\
2 & B & + \\
3 & C & - \\
\hline
\end{tabular}

Berdasarkan hasil uji diatas dapat dilihat bahwa ketiga sampel, hanya sampel yang teruji positif mengandung formalin . Oleh karena itu, sampel B kemudian diberikan perlakuan berupa perendaman dengan larutan garam 1, 2 dan 3\% dan perebusan di atas penangas air, pada Hot plate dipanaskan pada suhu $50^{\circ} \mathrm{C}$ dan $100^{\circ} \mathrm{C}$, selama 10,15 , dan 20 menit. Selanjutnya ditentukan kadar formalin menggunakan Spectrophotometer.

Tabel. 2

Uji Linieritas

\begin{tabular}{lcc}
\hline No & Konsentrasi $\mathbf{~ m g / l ~ ) ~}$ & Absorban \\
\hline 1 & 0,4625 & 0,1041 \\
2 & 0,9250 & 0,1465 \\
3 & 1,8500 & 0,2260 \\
4 & 4,6250 & 0,4965 \\
5 & 9,2500 & 0,9230 \\
\hline Rata - rata & & 0,3792 \\
Standar deviasi & & 0,00407 \\
Regresi & & 0,9999 \\
Batas Keberterimaan & & $\geq 0,995 *$ \\
\hline
\end{tabular}

Dari tabel 1 uji linearitas didapatkan hasil regresi linier 0,9999 yang berarti bahwa batas keberterimaan nilai regresi linearitas memenuhi syarat untuk melakukan pemeriksaan kadar formalin.

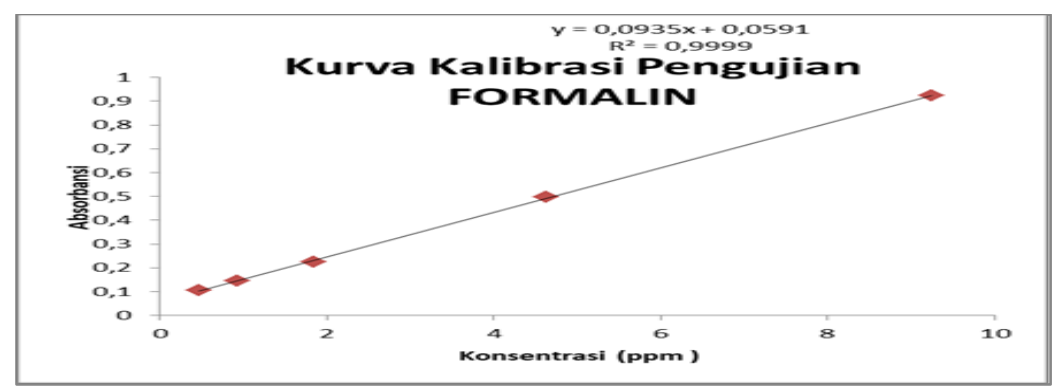

Gambar. 1

Kurva Kalibrasi 
Dari data hasil uji linieritas dapat disimpulkan bahwa uji linieritas memenuhi syarat keberterimaan, yaitu $\mathrm{R} \geq 0,995$

Tabel. 3

Kadar Formalin Setelah Perendaman Dengan

Varisi Waktu Dan Pemanasan

\begin{tabular}{|c|c|c|c|c|}
\hline $\begin{array}{c}\text { Kons. Larutan } \\
\text { garam }\end{array}$ & $\begin{array}{l}\text { Suhu kontak } \\
\text { (celcius) }\end{array}$ & $\begin{array}{l}\text { Waktu kontak } \\
\text { (menit) }\end{array}$ & Kode sampel & $\begin{array}{l}\text { Kadar sampel } \\
\quad(\text { ppm })\end{array}$ \\
\hline \multirow{6}{*}{$1 \%$} & \multirow{3}{*}{50} & 10 & A1 & 7,5155 \\
\hline & & 15 & $\mathrm{~A} 2$ & 7,5144 \\
\hline & & 20 & A3 & 7,5144 \\
\hline & \multirow{3}{*}{100} & 10 & B1 & 1,0929 \\
\hline & & 15 & $\mathrm{~B} 2$ & 1,0897 \\
\hline & & 20 & B3 & 2,1673 \\
\hline \multirow{6}{*}{$2 \%$} & \multirow{3}{*}{50} & 10 & $\mathrm{C} 1$ & 5,3679 \\
\hline & & 15 & $\mathrm{C} 2$ & 4,8141 \\
\hline & & 20 & $\mathrm{C} 3$ & 5,3674 \\
\hline & \multirow{3}{*}{100} & 10 & D1 & 1,0897 \\
\hline & & 15 & D2 & 1,0929 \\
\hline & & 20 & D3 & 2,1673 \\
\hline \multirow{6}{*}{$3 \%$} & \multirow{3}{*}{50} & 10 & E1 & 5,3679 \\
\hline & & 15 & $\mathrm{E} 2$ & 4,8141 \\
\hline & & 20 & E3 & 5,3679 \\
\hline & \multirow{3}{*}{100} & 10 & $\mathrm{~F} 1$ & 0,7722 \\
\hline & & 15 & $\mathrm{~F} 2$ & 0,7744 \\
\hline & & 20 & F3 & 0,8919 \\
\hline
\end{tabular}

Hasil penelitian, berdasarkan analisis uji anova, ada pengaruh pemanasan sampai mendidih $\left(100^{\circ} \mathrm{C}\right)$, $p$ value $=0,000$. Pada penelitian ini rata-rata kadar formalin dalam tahu sebelum perlakuan adalah 23,6 Ppm. Setelah perlakuan pemanasan sampai mendidih $\left(100^{\circ} \mathrm{C}\right)$ selama 10 menit, didapatkan kadar formalin rata-rata sebesar 0,9849 ppm, sehingga penurunan hasil pemeriksaan kadar formalin dalam tahu adalah 95,8 \%. Pada perlakuan pemanasan $50^{\circ} \mathrm{C}$ dengan konsentrasi garam $1 \%$ terjadi penurunan kadar dari 23,6 ppm menjadi 7,5147 ppm, sehingga penurunan menjadi $68 \%$.

Pada perlakuan pemanasan $100^{\circ} \mathrm{C}$, pada konsentrasi garam $1 \%$ terjadi penurunan dari 23,6 ppm menjadi 1,4499ppm, terjadi penurunan sebesar $93 \%$. Pada perlakuan $50^{\circ} \mathrm{C}$ dengan konsentrasi $2 \%$, terjadi penurunan kadar dari 23,6 ppm menjadi 5,1831 ppm, sehingga penurunan menjadi $78 \%$. Pada perlakuan pemanasan $100^{\circ} \mathrm{C}$, dengan konsentrasi $2 \%$, terjadi penurunan kadar dari 23,6 ppm menjadi 1,4499 ppm sehingga penurunan kadar mencapai $93 \%$. Pada pemanasan $50^{\circ} \mathrm{C}$, dengan konsentrasi $3 \%$, terjadi penurunan kadar dari 23,6 ppm menjadi 5,1833 ppm sehingga penurunan mencapai $78 \%$. Pada pemanasan $100^{\circ} \mathrm{C}$, dengan konsentrasi $3 \%$ terjadi penurunan kadar dari $23,6 \mathrm{ppm}$ menjadi 0,8128 ppm sehingga penurunan mencapai $96 \%$. 


\section{PEMBAHASAN}

Perebusan dalam larutan garam akan menurunkan residu formalin pada tahu karena tekanan osmosis antara cairan sel padatan tahu dengan larutan garam. Perebusan menyebabkan berlangsungnya proses diffusi cairan dari padatan tahu kedalam larutan garam. Proses diffuse ini akan mempengaruhi tekanan osmosis, waktu perebusan dan suhu larutan garam. Semakin besar perbedaan osmosis, semakin lama waktu perebusan, akan semakin banyak formalin yang berdiffusi kelarutan garam sampai tercapai kondisi larutan jenuh. Demikian juga semakin tinggi suhu larutan perendam akan semakin cepat proses diffuse larutan formalin kedalam larutan perendam, sehingga semakin banyak formalin yang tercuci (Ernawati et al., 2017).

Garam dengan konsentrasi yang tinggi dapat menyerap kadar air pada sampel tahu putih yang memiliki konsentrasi lebih rendah (bersifat higroskopis). Sehingga nantinya akan terjadi proses osmosis dan proses pertukaran garam semakin lambat bahkan berhenti sama sekali karena terserapnya air dalam tahu ke dalam air garam perendaman menyebabkan formalin pada tahu ikut larut. Formalin dapat larut dalam air garam karena garam merupakan golongan surfaktan yang dapat menimbulkan reaksi saponifikasi yaitu mempunyai daya bersih terhadap formalin (Manalu, Musthari, 2019).

Penurunan kadar formalin tahu putih tidak konsisten atau penyerapan formalinnya selama perendaman tidak sama walaupun polanya sama, bisa terjadi karena dipengaruhi oleh tekstur dan kandungan kadar air yang terdapat sampel tahu putih. Ketika kandungan air pada tahu lebih tinggi maka formalin akan lebih banyak terikat pada tahu dibanding pada tahu dengan kandungan air rendah. Tahu yang berformalin mempunyai interaksi yang melibatkan senyawa formaldehid dengan air, yang menyebabkan rendahnya kadar air pada tahu yang berformalin. Sedangkan tekstur tahu yang telah diberi formalin menjadi keras dibandingkan tanpa menggunakan formalin. Kerasnya tekstur tahu disebabkan karena formalin masih mengendap dalam sampel sehingga tahu menjadi sukar hancur. Factor lingkungan juga mempengaruhi proses penyerapan formalin seperti suhu. Ketika protein diperhadapkan dengan peningkatan suhu yang melebihi batas normal, sejumlah ikatan molekul protein menjadi melemah. Suhu yang diharapkan saat proses perendaman dengan formalin ialah pada suhu ruangan (20-250C) (Manalu, Musthari, 2019).

Kadar formalin dalam tahu dapat juga dikurangi dengan perebusan dalam air, ini dikarenakan sifat formalin dapat larut dalam air, sehingga dengan perebusan dalam air formalin yang ada pada tahu akan larut dalam pelarutnya yaitu air. Hal tersebut disebabkan karena adanya perbedaan tekanan osmosis antara daging tahu dengan larutan perebus air, sehingga terjadi perpindahan molekul air dari tahu, melarut ke perebusan. Melalui proses perebusan molekul ini maka formalin mempunyai sifat larut dalam air karena formalin bersifat polar dan juga air juga bersifat polar.

Hasil penelitian yang dilakukan oleh Sirait (2016) menyatakan bahwa perendaman tahu dalam larutan garam $2,5 \%$ pada suhu $30^{\circ} \mathrm{C}$ dan waktu perendaman 20 menit dapat menurunkan residu formalin 43,33\%. Hal ini sesuai dengan Ita (2016) mengatakan, karakteristik formalin mudah larut dalam air sampai dengan konsentrasi $55 \%$.

Penelitian Burhan (2018) semakin besar konsentrasi cuka makan yang digunakan semakin besar kadar formalin yang berhasil direduksi dari dalam ikan asin teri nasi. Uji Anova juga membuktikan secara signikan (Sig. <0,05) yang menunjukkan konsentrasi cuka makan berpengaruh signifikan terhadap kadar formalin dalam ikan asin teri nasi. Hal ini disebabkan semakin tinggi konsentrasi cuka makan, maka semakin banyak ion $\mathrm{H}+$ yang dihasilkan dan berkesempatan beraksi dengan protein metilol maupun protein cross- 
licking membentuk formaldehida lagi yang terlarut dalam air. Pada tiap waktu perendaman, teramati bahwa cuka makan $20 \%$ terbukti paling banyak mampu menurunkan kadar formalin hingga 90\%.

Penelitian Suprapti et al., (2017) menunjukkan bahwa konsentrasi larutan air garam $5 \%$, dapat menurunkan kadar formalin rata-rata $2.702 \mathrm{ppm}(16 \%)$; konsentrasi $10 \%$ menurunkan $5.741 \mathrm{ppm}$ (34\%); dan konsentrasi 15\%, dapat menurunkan $8.655 \mathrm{ppm}$ (51\%). Perendaman selama 15 menit dapat menurunkan formalin rata-rata $5.714 \mathrm{ppm}$ (33\%); perendaman 30 menit menurunkan $5.261 \mathrm{ppm} \mathrm{(31 \% );} \mathrm{dan} \mathrm{perendaman} 60$ menit menurunkan 6.122 ppm 36). Interaksi konsentrasi 15\% selama 60 menit menurunkan kadar formalin tahu optimal rata-rata sebesar $9.575 \mathrm{ppm}$ (62\%). Semua variasi konsentrasi larutan air garam dan variasi waktu perendaman dapat menurunkan kadar formalin pada tahu putih.

Penelitian Cahyadi et al., (2020) hasil uji kuantitatif perendaman air kunyit, air cuka dan air garam selama 60 menit menunjukkan penurunan konsentrasi formalin berturut-turut sebesar $22,56 \%, 25,54 \%$ dan $55,33 \%$. Larutnya formalin pada air garam menyebabkan kadar formalin dalam tahu berkurang. Kemampuan melarutkan yang tinggi yang dimiliki air garam inilah yang menyebabkan efektivitas perendaman dengan air garam memiliki angka yang tertinggi dalam mereduksi kadar formalin pada tahu jika dibandingkan dengan perendaman lainnya yaitu air kunyit dan air cuka.

Penelitian Rahmi, Razak (2018) menunjukkan bahwa penurunan kadar formalin tertinggi terdapat pada perlakuan perendaman dalam larutan garam selama 15 menit serta pengolahan dengan cara dikukus dan digoreng. Hal ini dikarenakan sifat formalin larut dalam air dan mudah terurai jika dipanaskan. Formalin juga sangat reaktif dalam kondisi basa, ketika direndam dilarutan garam kadar formalin turun karena garam memiliki sifat basa, selain itu titik didih formalin juga rendah sehingga kandungan formalin pada makanan akan mudah menguap saat perebusan atau penggorengan. Hasil uji kualitatif tahu yang positif dan negatif mengandung formalin memiliki karakteristik yang berbeda . Perbedaan karakteristik tahu putih dan tahu kuning terdapat pada warna, tekstur, dan aroma. Tahu putih yang positif mengandung formalin rata-rata memiliki warna putih pucat sampai kekuningan dan mengkilap, tekstur yang padat, kenyal hingga keras, dan aroma yang sedikit khas tahu dan tahu kuning rata-rata memiliki warna kuning muda mengkilap hingga pekat, apabila dipotong terdapat warna putih dibagian tengah, tekstur yang padat dan kenyal, dan tidak memiliki aroma khas tahu, sedangkan tahu putih yang negatif formalin memiliki warna putih bersih, tekstur lunak dan mudah hancur, dan aroma khas tahu dan tahu kuning yang negatif formalin memiliki warna kuning pekat, tekstur lunak, dan memiliki aroma sedikit khas tahu.

Penelitian yang dilakukan oleh Nuranisa et al., (2018) apabila tahu disimpan lebih dari dua hari, maka perlu ditambahkan pengawet yang aman untuk dikonsumsi, dengan penambahan garam dapur, efek dari garam berperan sebagai pengawet, sekaligus sebagai penghambat selektif pada mikroorganisme pencemar tertentu.

Pada proses perendaman dengan larutan garam 1, 2 dan $3 \%$, terjadi penurunan kadar formalin dalam tahu, tetapi lebih baik direndam pada larutan garam $1 \%$, kemudian direbus sampai mendidih selama 10 menit. Penelitian Sugiarti, Aminah (2020) yang dilakukan di laboratorium Toksikologi Jurusan Analis Kesehatan Poltekkes Tanjungkarang. Pengukuran kadar formalin menggunakan spektrofotometer. Hasil penelitian menunjukkan ada penurunan kadar formalin setelah direndam dengan air garam selama 15 menit, 30 menit, 60 menit dan 90 menit, yaitu 37, 3105\%, 49, 3890\%, $54,7773 \%, 72,1172 \%$. 
Masa simpan tahu yang sangat singkat menyebabkan pedagang di pasar banyak yang tidak ingin rugi dengan barang dagangan mereka jika tidak habis terjual, akan tetapi oleh minimnya pengetahuan masyarakat tentang bahayanya formalin terhadap tubuh manusia.Padahal tahu merupakan makanan yang banyak diminati di Indonesia, selain murah, praktis dan mudah didapat. Selain itu tahu juga memiliki nilai gizi yang sangat tinggi yang dibutuhkan tubuh, untuk menghasilkan protein.

Bahan tambahan pangan atau disingkat BTP sangat mempengaruhi sifat dan bentuk pangan sehingga textur dan sifat makanan menjadi berubah, demikian juga tahu yang ditambahkan bahan pengawet formalin, karena kemampuannya dalam menghambat pertumbuhan mikroba, jamur yang menjadi penyebab pembusukan.Akan tetapi sebenarnya formalin adalah makanan tambahan yang dilarang ditambahkan pada produk makanan atau minuman karena bersifat toksik, dan akumulatif dalam tubuh.

Padahal tahu adalah bahan makanan yang sering dikonsumsi setiap hari, sebaiknya sebelum mengkonsumsi tahu lebih baik secara sederhana, direbus dulu dengan penambahan garam, untuk menghindari paparan formalin dalam jangka pendek maupun panjang.

Formalin sebenarnya sangat umum digunakan dalam kehidupan sehari-hari. Di sector industri, formalin sangat banyak manfaatnya, misalnya sebagai anti bakteri atau pembunuh kuman, sehingga formalin sering dimanfaatkan sebagai pembersih lantai, kapal, gudang, pakaian bahkan juga dapat dipergunakan sebagai pembunuh lalat dan berbagai serangga lain.

Formalin mempunyai kemampuan untuk mengawetkan makanan karena gugus aldehida yang bersifat mudah bereaksi mudah bereaksi dengan protein membentuk senyawa methylene (-NCHOH). Dengan demikian, ketika makanan berprotein disiram atau direndam larutan berformalin maka gugus aldehida dari formaldehid perendaman air garam (Rahmadhani et al., 2017).

Besarnya manfaat formalin dibidang industri ini, ternyata banyak disalahgunakan untuk penggunaan pengawetan industri makanan.Salah satunya adalah makanan cepat saji, tahu, karena salah satu kualitas tahu secara fisik adalah kekenyalannya.

\section{SIMPULAN}

Pada penelitian ini ada pengaruh pemberian larutan garam terhadap penurunan kadar formalin pada tahu. Lebih spesifik dan sangat signifikan perendaman pada larutan garam $1 \%$ dan dipanaskan pada suhu $100^{\circ} \mathrm{C}$ selama 10 menit.

\section{SARAN}

Untuk masyarakat menggunakan garam, atau dengan cara merebus tahu putih dapat menurunkan kadar formalin dalam tahu putih. Sedangkan bagi peneliti perlu diadakan penelitian, untukpengurangan formalin dalam tahu, pada suhu $100^{\circ} \mathrm{C}$, tanpa mengurangi kadar protein .

\section{DAFTAR PUSTAKA}

Amilustavilova, N., Sayekti, S., \& Setyorini, E. (2017). Pengaruh Perebusan dalam Air Mendidih terhadap Kadar Formalin pada Tahu (Studi Kasus di Pasar Legi Jombang). Sekolah Tinggi Ilmu Kesehatan Insan Cendekia Medika Jombang

Burhan, A. H. (2018). Penurunan Kadar Formalin dalam Ikan Asin Teri Nasi melalui Perendaman Dalam Cuka Makan. Jurnal Ilmu Kesehatan Bhakti Setya Medika, 3, 22-30 
Cahyadi, K. D., Yuliawati, A. N., \& Lestari, G. A. D. (2020). Studi Efektivitas Reduksi Kadar Formalin pada Tahu dengan Perendaman Air Kunyit, Air Cuka dan Air Garam dalam Upaya Penyediaan Pangan Aman. Jurnal Ilmiah Ibnu Sina (JIIS), 5(1), 156-164. https://doi.org/10.36387/jiis.v5i1.409

Ernawati, A., Pangestu, R. D., \& Widajanti, L. (2017). Efektifitas Perendaman Air Hangat dan Air Garam terhadap Penurunan Kadar Formalin Ikan Teri Asin di Tingkat Pedagang Pasar Kota Semarang. Jurnal Kesehatan Masyarakat (EJournal)

Iftriani, I., Wahyuni, S., \& Amin, H. (2016). Analisis Kandungan Bahan Pengawet Formalin pada Tahu yang Diperdagangkan di Pasar Tradisional Kota Kendari (Pasar Panjang, Pasar Anduonohu, Pasar Basah dan Pasar Baruga). J. Sains Dan Teknologi Pangan

Indri, M. H., Mukaromah, A. H., \& Wardoyo, F. A. (2018). Penurunan Kadar Formalin pada Tahu Menggunakan Larutan Jeruk Menggunakan Jeruk Nipis (Citrus Aurantium) Berdasarkan Variasi Konsentrasi dan Lama Perendaman. http://repository.unimus.ac.id

Ita, I. (2016). Cara Mudah Hilangkan Formalin pada Makanan Anda. https://news.labsatu.com/cara-mudah-hilangkan-kandungan-formalin-makanan---anda

Manalu, A., \& Musthari, M. (2019). Pengaruh Perendaman Tahu yang Berformalin dengan Variasi Konsentrasi Larutan Garam. Politeknik Kesehatan Kemenkes RI Medan

Nuranisa, H. A., Prasetyaningsih, Y., \& Marlina, L. (2018). Pengaruh Bubuk Bawang Putih dan Garam Dapur terhadap Masa Simpan Tahu pada Suhu Kamar dalam Lingkungan Asam. Jurnal Teknik: Media Pengembangan Ilmu Dan Aplikasi Teknik. https://doi.org/10.26874/jt.vol16no2.57

Pusparini, I. D., \& Triyantoro, B. (2018). Deskripsi Kadar Formalin pada Tahu Putih yang Dijual di Pasar Segamas Kabupaten Purbalingga Tahun 2017. Keslingmas, 37(2), 117-125. https://doi.org/10.31983/keslingmas.v37i2.3834

Rahmadhani, F., Safrida, S., \& Djufri, D. (2017). Pengaruh Perendaman Berbagai Larutan terhadap Penurunan Kadar Formalin pada Ikan Asin Kembung (Scomber canagorta) di Pasar Lambaro Aceh Besar. Jurnal Ilmiah Mahasiswa Keguruan Dan Ilmu Pendidikan Unsyiah, 2(3)

Rahmi, S. R. O., \& Razak, M. (2018). Pengaruh Perendaman dalam Larutan Cuka dan Larutan Garam terhadap Keamanan Pangan Tahu di Pasar Tradisional dan Swalayan di Kota Sidoarjo (Kajian Kandungan Formalin). Jurnal Ilmiah-Vidya, 26(2), 51-59

Sirait, M. D. R., Hanum, T., \& Rangga, A. (2016). Pengaruh Perendaman dalam Larutan Garam terhadap Penurunan Residu Formalin pada Tahu. Universitas Lampung

Sugiarti, M., \& Aminah, S. (2020). Pengaruh Waktu Perendaman Air Garam terhadap Penurunan Kadar Formalin pada Cumi- Cumi Asin. Jurnal Analis Kesehatan, $8(2), 58-62$

Suprapti, S., Utomo, B., \& Gunawan, A. T. (2017). Efektivitas Variasi Konsentrasi Larutan Air Garam dan Variasi Waktu Perendaman dalam Menurunkan Kadar Formalin pada Tahu Putih. Buletin Keslingmas, 36(2), 116-122. https://doi.org/10.31983/keslingmas.v36i2.3016 
Widayona, U. Y., \& Nasution, S. B. (2018). Analisa Penurunan Kadar Formalin pada Tahu Berformalin dengan Variasi Temperature yang Dijual di Pasar Aksara Medan. Politeknik Kesehatan Kemenkes RI Medan 